ISSN 1392-3196 / e-ISSN 2335-8947

Zemdirbyste-Agriculture, vol. 104, No. 4 (2017), p. 305-310

DOI $10.13080 /$ z-a.2017.104.039

\title{
Fungal diversity as influenced by soil characteristics
}

\author{
Sonja TANČIĆ ŽIVANOV ${ }^{1}$, Ljiljana NEŠIĆ ${ }^{2}$, Radivoje JEVTIĆ ${ }^{1}$, Milivoj BELIĆ ${ }^{2}$, \\ Vladimir ĆIRIĆ ${ }^{2}$, Mirjana LALOŠEVIĆ ${ }^{1}$, Jelica VESELIĆ ${ }^{1}$ \\ ${ }^{1}$ Institute of Field and Vegetable Crops \\ Maksima Gorkog 30, 21000 Novi Sad, Serbia \\ E-mail: sonja.tancic@ifvens.ns.ac.rs \\ ${ }^{2}$ University of Novi Sad \\ Trg Dositeja Obradovića 8, 21000 Novi Sad, Serbia
}

\begin{abstract}
The purpose of this study was to determine the influence of soil properties on the biodiversity of soil fungi. An analysis of the fungal diversity of eight different soil types with different soil texture, organic matter, carbonate content, $\mathrm{pH}$, cation exchange capacity and different land uses identified a total of 38 different species grouped in 24 genera. Among all soil fungi identified, the most common were organic matter decomposers. The species most frequently identified were Aspergillus spp., Alternaria sp., Fusarium spp., Mortierella sp. and Penicillium spp. The greatest similarities between fungal communities were seen in arable land with a low or moderate cation exchange capacity and organic matter content, while the least similarities were found between forest Cambisol $(C M)$ and garden soils. The Shannon-Wiener diversity index indicated the highest diversity in Chernozem $(\mathrm{CH})$, Fluvisol $(F L)$ and Arenosol $(A R)$ all used as arable land or garden soil, while the lowest diversity was recorded in a Gleysol $(G L)$ under a meadow, caused by poor aeration and a poor water regime. Canonical correlation analysis (CCA) showed the relationship of soil fungi with all soil environmental factors analysed and indicated that certain soil fungi were positively related to organic matter, sand and clay content.
\end{abstract}

Key words: biodiversity, land use, soil fungi.

\section{Introduction}

Soils are one of the largest biodiversity reservoirs, and biological diversity in the soil is several times greater than on the surface. The biochemical activity of microorganisms affects the pedogenetic process and thus participates in the creation and maintenance of soil fertility. Fungi play a key role in ecosystem function, primarily due to the decomposition of plant residues (Bridge, Spooner, 2001). Quantitative and qualitative improvement of organic matter (OM) in the soil is mainly found in agroecosystems that contain many fungi communities, but the mechanisms that lead to this improvement are not fully understood (Six et al., 2006). Critical stages of lignin decomposition are almost completely carried out by soil fungi, while the cleavage of complex biomolecules in the soil, such as cellulose and tannin, is also caused by fungal enzymatic activity (Cannon, 1999). Many fungal species grow and develop in the soil, but only a few have adapted to the unfavourable conditions prevailing in acidic or alkaline soils (Jeewon, Hyde, 2007). Some studies have shown the influence of edaphic properties on the growth and development of fungi (Lauber et al., 2008; Rousk et al., 2010).

Different subtypes of Chernozem $(\mathrm{CH})$ are dominant at the investigated area, which is the best soil for agricultural production. Chernozem provide optimal opportunity for all types of field production. The river valleys are abundantly represented by different types of alluvial soils (Fluvisol, FL) and are the most productive land for vegetable production. Fluvisol ecological characteristics depend largely on the flooding and groundwater regime (Nešić, 2011). Meadow and gleyed soils are also high quality soils, but their production potential can be realized only when climatic conditions are optimal. Most of the Vertisol $(V R)$ in Vojvodina, Serbia are heavy textured, and thus have unfavourable water-air properties (Belić et al., 2011). Cambisol (CM) occur on mountain terrain that is suitable for production of fruits and grapes. Arenosol $(A R)$ in Subotička and Deliblatska sandstone represent the area with the prevailing initial soils (Nešić, 2011).

This paper presents an analysis of the abundance of fungi population in eight soil types that have very different physical and chemical properties as well as different land use. Soil texture, organic matter content, carbonate content, $\mathrm{pH}$ and cation exchange capacity (CEC) can all significantly affect the diversity and abundance of soil fungi, which is why the aim of this study was to determine the influence of soil properties on the biodiversity of fungi. It is likely that we currently

Please use the following format when citing the article:

Tančić Živanov S., Nešić L., Jevtić R., Belić M., Ćirić V., Lalošević M., Veselić J. 2017. Fungal diversity as influenced by soil characteristics. Zemdirbyste-Agriculture, 104 (4): 305-310 DOI 10.13080/z-a.2017.104.039 
know at least $30 \%$ of the total diversity of soil fungi, and the number of species of soil fungi is expected to be considerably higher than the 3300 species currently known (Gams, 2007). This research contributes to a better knowledge of the biodiversity and the mycobiota present in soil samples of different types and usage.

\section{Materials and methods}

Analyses of soil samples. Soil samples were taken in the summer of 2013, from different soil groups (WRB, 2014) in Serbia: Arenosol (AR) (N 4607'09", E

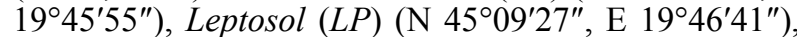

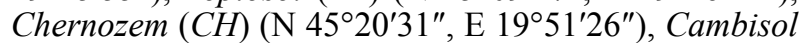

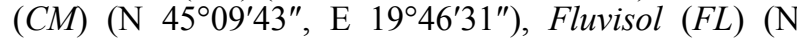

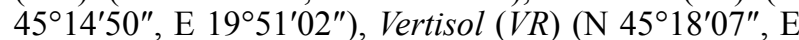

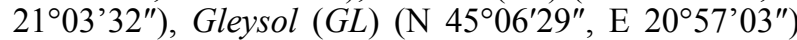

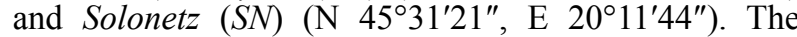
representative soil samples were taken from the surface (0-20 cm depth) layer using a soil probe. At every sampling point three replicates were taken approximately $10 \mathrm{~m}$ apart. Some physical and chemical properties of soil were determined: 1) texture - using the pipette method (Na-pyrophosphate is used for preparing soil samples for analysis) (Thun et al., 1955); 2) $\mathrm{pH}$ value - potentiometrically in the suspension of soil and water, and soil and $1 \mathrm{M} \mathrm{KCl}(1: 2.5, \mathrm{w} / \mathrm{v}) ; 3) \mathrm{CaCO}_{3}$ content volumetrically, using Scheibler calcimeter (SSR Uniglas, Serbia); 4) organic matter (OM) content - by dichromate wet oxidation method; 5) cation exchange capacity (CEC) - soil extraction with sodium acetate and ammonium acetate, and the concentration of $\mathrm{Na}^{+}$in the extract, by inductively coupled plasma.

Fungal isolation and identification. Selective water agar media amended with streptomycin were used to isolate fungi from soil samples by the particle-plating method. The particle-plating method was used, because it usually yields higher numbers of taxa than the dilution plating method. Soil particles weighing $0.0001 \mathrm{~g}$ were placed in a Petri dish with medium ( 5 pieces per Petri dish, in seven replicates). A total of 35 soil pieces $(0.0035$ $\mathrm{g}$ of soil dry weight) per sample were analysed after seven days of incubation at room temperature $\left(25-28^{\circ} \mathrm{C}\right)$. The emerging fungal colonies were observed microscopically and transferred to suitable medium for further analysis of morphological characteristics. Final identification was done according to the keys of Leslie and Summerell (2006) and Watanabe (2010). The total number of colonies of each species was recorded, and for further data analyses, the number of colonies of fungus species $0.0035 \mathrm{~g}^{-1}$ dry weight soil/soil type was converted to the abundance of soil fungus - number of colony forming units (CFU) per g of dry weight soil/soil type.
Data analysis. The Sorensen index of similarity (IS) was used to compare fungal communities in different soil types according to the formula:

$$
\mathrm{IS}=(2 \mathrm{C} / \mathrm{A}+\mathrm{B}) \times 100 \text {, }
$$

where $\mathrm{C}$ is the number of species found in both $\mathrm{A}$ and $\mathrm{B}$ soil samples, $\mathrm{A}$ - the total number of species found in soil sample A, B - the total number of species found in soil sample B.

The diversity of samples of different soil types was analysed by the Shannon-Wiener index $\left(H^{\prime}\right)$ and calculated according to the formula:

$$
H^{\prime}=-\sum_{i=1}^{n} p_{i} \ln p_{i}
$$

where $p_{i}$ is the proportion of number of colonies of the $i$-th species to the total number of colonies when $i=1,2,3, \ldots ., \mathrm{n}$.

The relationship between soil fungi and soil physical and chemical properties was analysed using the ordination method with canonical correlation analysis (CCA).

\section{Results and discussion}

Analyses of physicaland chemical soilproperties. Physical and chemical properties of eight different soil types investigated (Table 1) were consistent with previous results of the authors who investigated those soil types in Serbia (Belić et al., 2011; Nešić, 2011). Arenosols are formed on Aeolian sand characterized by a very fine sandy texture and therefore having an unfavourable water and air regime. Ranker has a coarse sandy loam texture. In contrast, Chernozem has a favourable loamy clay texture, as well as Cambisol which is characterized by a loamy clay texture. The Fluvisol investigated was characterized by clayic loamy texture while the Solonetz was characterized by a loamy clay texture and was moderately humic. CEC is one of the most important factors affecting soil fertility, because it prevents leaching and the loss of cations from the soil. The CEC can vary in a very wide range in different soils (Schiefer et al., 2015), from 1-2 to more than 100 $\mathrm{cmol}^{+} \mathrm{kg}^{-1}$, but in most of the soils in Vojvodina, it usually varies in the range of $25-35 \mathrm{cmol}^{+} \mathrm{kg}^{-1}$ (Ćirić et al., 2016), as shown in Table 1.

Diversity of soil fungi. An analysis of the biodiversity of eight different soil types identified a total of 38 different fungal species grouped in 24 genera. The total number of species identified in samples S1S8 was $10,15,17,9,9,16$ and 16, respectively. The most common soil fungi identified were organic matter decomposers, but there were many phytopathogenic fungal species such as Fusarium spp. (eight different species), Macrophomina phaseolina, Dreschlera sp. and Bipolaris sp., mostly found in soil samples from arable

\begin{tabular}{|c|c|c|c|c|c|c|c|c|c|c|c|}
\hline \multirow{2}{*}{$\begin{array}{l}\text { Sample } \\
\text { code }\end{array}$} & \multirow{2}{*}{$\begin{array}{l}\text { Soil } \\
\text { group }\end{array}$} & \multirow{2}{*}{$\begin{array}{l}\text { Land } \\
\text { use }\end{array}$} & \multicolumn{4}{|c|}{ Particles content $\%$} & \multirow{2}{*}{$\begin{array}{c}\text { OM } \\
\%\end{array}$} & \multirow{2}{*}{$\begin{array}{c}\mathrm{CaCO}_{3} \\
\%\end{array}$} & \multicolumn{2}{|c|}{$\mathrm{pH}$} & \multirow{2}{*}{$\begin{array}{c}-\quad \mathrm{CEC} \\
\mathrm{cmol}^{+} \mathrm{kg}^{-1}\end{array}$} \\
\hline & & & $\begin{array}{c}\text { coarse } \\
\text { sand }\end{array}$ & $\begin{array}{l}\text { fine } \\
\text { sand }\end{array}$ & silt & clay & & & $1 \mathrm{~N}$ & $\mathrm{H}_{2} \mathrm{O}$ & \\
\hline S1 & ol & forest & $1.4 \pm 0.5$ & $3.2 \pm 1.7$ & .5 & .7 & 9 & 0 & J & 30 & \pm 2.9 \\
\hline S2 & Leptosol & meadow & $52.7 \pm 3.7$ & $26.9 \pm 6.2$ & $14.4 \pm 2.7$ & $6.0 \pm 0.9$ & $8.82 \pm 0.41$ & $0 \pm 0$ & 6.0 & .12 & $=5.1$ \\
\hline S3 & Arenosol & arable & $9.7 \pm 1.8$ & $77.1 \pm 2.3$ & $6.9 \pm 1.5$ & $6.3 \pm 1.0$ & $1.69 \pm 0.08$ & $2.7 \pm 0.4$ & $+7.4 c$ & .07 & \pm 2.1 \\
\hline S4 & Solonetz & rable & $6.4 \pm 1.7$ & $27.7 \pm 1.5$ & $36.3 \pm 2.7$ & $29.6 \pm 2.4$ & $2.73 \pm 0.12$ & $0 \pm 0$ & 6.00 & 1.65 & $525.0 \pm 2.4$ \\
\hline S5 & Gleysol & meadow & $3.4 \pm 0.6$ & $26.4 \pm 1.3$ & $24.6 \pm 0.6$ & $45.6 \pm 1.8$ & $3.69 \pm 0.22$ & $3.1 \pm 0.3$ & $7.03 \pm 0.06$ & $7.70 \pm$ & $230.0 \pm 1.8$ \\
\hline S6 & Vertisol & garden & $1.6 \pm 0.5$ & $26.8 \pm 2.0$ & $31.6 \pm 2.1$ & $40.1 \pm 0.7$ & $3.66 \pm 0.28$ & $0.3 \pm 0.1$ & $5.99 \pm 0.07$ & $6.98 \pm 0.06$ & $629.6 \pm 1.5$ \\
\hline S7 & Fluvisol & garden & $1.8 \pm 0.1$ & $39.4 \pm 1.5$ & $36.7 \pm 2.5$ & $22.1 \pm 1.0$ & $1.87 \pm 0.19$ & $3.7 \pm 0.3$ & $7.17 \pm 0.01$ & $8.01 \pm 0.03$ & $322.4 \pm 3.1$ \\
\hline S8 & Chernozem & arable & $0 \pm 0$ & $36.2 \pm 1.1$ & $30.2 \pm 0.7$ & $33.6 \pm 0.4$ & $2.54 \pm 0.14$ & $0.4 \pm 0.1$ & $6.00 \pm 0.05$ & $7.00 \pm 0.07$ & $721.9 \pm 0.9$ \\
\hline
\end{tabular}

Table 1. Physical and chemical properties of the soil types investigated (mean values \pm SD)

$\mathrm{OM}$ - organic matter, CEC - cation exchange capacity 
lands or gardens. A few species were isolated that are known to be good antagonists to phytopathogenic species and usable for biological control, e.g., Trichoderma spp., Gliocladium sp. and Penicillium spp. (Table 2).
The biomass of fertile soils can be even up to $20 \mathrm{t} \mathrm{ha}^{-1}$, and the largest share of the total amount of soil biomass is $98 \%$ fungi, $1.90 \%$ bacteria and up to $0.10 \%$ actinomycetes (Lee, Pankhurst, 1992). The CFU

Table 2. The abundance of soil fungi ( $\mathrm{CFU} \mathrm{g}^{-1}$ dry weight soil/soil sample $\left.\times 10^{3}\right)$ identified in eight soil types

\begin{tabular}{|c|c|c|c|c|c|c|c|c|c|}
\hline \multirow{2}{*}{ Species } & \multicolumn{8}{|c|}{ Abundance $\left(\mathrm{CFU} \mathrm{g}^{-1} \times 10^{3}\right)$} & \multirow{2}{*}{$\begin{array}{c}\text { Frequency } \\
\%\end{array}$} \\
\hline & $\mathrm{S} 1$ & $\mathrm{~S} 2$ & S3 & $\mathrm{S} 4$ & S5 & S6 & S7 & S8 & \\
\hline Acremonium sp. & & & & & & & 0.571 & 0.285 & 25.00 \\
\hline Alternaria sp. & 0.285 & 0.285 & 0.285 & 0.857 & 0.285 & & 0.857 & & 75.00 \\
\hline Aspergillus fumigatus & & & & 0.285 & & & & & 12.50 \\
\hline F4 A. niger & & & 1.428 & & & & & 2.857 & 25.00 \\
\hline A. parasiticus & & & 0.857 & 0.285 & & & 0.285 & & 25.00 \\
\hline F6 A. section clavati sp. & & & & 0.285 & & & & & 12.50 \\
\hline Aspergillus sp. & 0.857 & & & & & & 0.857 & 0.285 & 50.00 \\
\hline Bipolaris sp. & & 0.285 & & & & & 0.571 & & 25.00 \\
\hline Chaetomium $\mathrm{sp}$. & & & 0.285 & 0.285 & & & & 0.571 & 37.50 \\
\hline F10 Cylindrocarpon sp. & & & 0.285 & & & & & 0.571 & 25.00 \\
\hline F11 Dreschlera sp. & & & 0.285 & & & & & & 12.50 \\
\hline F12 Epicoccum $\mathrm{sp}$. & & & & & & 0.285 & & & 12.50 \\
\hline F13 Fusarium graminearum & & & & & & & & 0.571 & 12.50 \\
\hline F14 F. oxysporum & & 4.285 & 2.285 & 5.714 & 2.857 & 2.285 & 4.000 & 2.285 & 87.50 \\
\hline F15 F. proliferatum & & & & & 0.285 & 0.285 & & & 25.00 \\
\hline F16 F. sambucinum & & & & & & & 0.571 & & 12.50 \\
\hline F17 F. semitectum & & & & & & & 0.571 & & 12.50 \\
\hline F18 F. solani & & 0.571 & 5.428 & 4.000 & 5.714 & 5.714 & 4.000 & 2.000 & 87.50 \\
\hline F19 F. subglutinans & & & & & & 0.285 & & & 12.50 \\
\hline F20 Fusarium sp. & & & 0.571 & & 0.285 & & & & 25.00 \\
\hline F21 Gliocladium sp. & & & & & & 0.285 & 0.857 & & 25.00 \\
\hline F22 Hyalodendron sp. & 1.428 & 2.85 & & 0.285 & & & & & 37.50 \\
\hline F23 Macrophomina phaseolina & & & & & & 0.857 & 1.142 & 3.428 & 37.50 \\
\hline F24 Mortierella $\mathrm{sp}$ & 2.571 & 1.428 & 1.714 & 2.857 & 1.714 & 1.142 & 1.714 & 1.714 & 100.00 \\
\hline F25 Mucor sp. & & 1.428 & 0.571 & & & & & 0.285 & 25.00 \\
\hline F26 Paecilomyces sp. & 2.285 & 0.571 & & & 0.285 & & & & 37.50 \\
\hline F27 Penicillium sp. 1 & 2.857 & 2.571 & 2.571 & 2.857 & 3.142 & 0.857 & 0.857 & 3.428 & 100.00 \\
\hline F28 Penicillium sp. 2 & 3.142 & 1.428 & 1.714 & 2.000 & 1.714 & 0.571 & & 3.714 & 87.50 \\
\hline F29 $\quad$ Penicillium sp. 3 & 1.428 & 0.857 & 0.571 & & & & & 0.857 & 50.00 \\
\hline F30 Periconia $\mathrm{sp}$ & & & & & & & 0.285 & & 12.50 \\
\hline F31 Ramichloridium sp. & & & & & & & 0.571 & & 12.50 \\
\hline Rhizopus sp. & & 1.428 & & & & & & 0.285 & 25.00 \\
\hline F33 Micelia sterilia & 0.285 & 0.285 & & & & & & 0.285 & 37.50 \\
\hline F34 Micelia with pycnidia & & & 0.571 & & & 1.142 & & & 25.00 \\
\hline F35 Scolecobasidium sp. & & & 0.857 & & & & & & 12.50 \\
\hline F36 $\quad$ Trichoderma sp. 1 & 0.857 & 1.428 & 0.571 & & & & & & 37.50 \\
\hline F37 $\quad$ Trichoderma sp. 2 & & 0.857 & & & & & & & 12.50 \\
\hline F38 Ulocladium $\mathrm{sp}$. & & & & & & & 0.285 & & 12.50 \\
\hline $\begin{array}{l}\text { Total per sample } \\
\left(\mathrm{CFU} \mathrm{g}^{-1} \times 10^{3}\right)\end{array}$ & 15.99 & 17.99 & 20.85 & 19.43 & 16.28 & 13.99 & 17.99 & 23.42 & \\
\hline Total No. of species per sample & 10 & 15 & 17 & 9 & 9 & 11 & 16 & 16 & \\
\hline
\end{tabular}

S1 - Cambisol, S2 - Leptosol, S3 - Arenosol, S4 - Solonetz, S5 - Gleysol, S6 - Vertisol, S7 - Fluvisol, S8 - Chernozem

of microorganisms per gram of soil is vast and usually in a range from $10^{2}$ to $10^{7}$ depending on the group of organisms and agroecological factors. In this study the CFU of fungi per gram of soil varied from $0.285 \times 10^{3}$ to $5.714 \times 10^{3}$. Variation in the total number of soil fungal species and their abundance can be noticed from one soil type to another. Fungal species that were present in all soil types (frequency 100\%) were Mortierella sp. and Penicillium sp. 1 (Table 2). On the other hand, some species appeared only in one soil type (frequency $12.50 \%$ ) such as Aspergillus fumigatus, A. section clavati sp., Dreschlera sp., Epicoccum sp., Fusarium graminearum, F. sambucinum, F. semitectum, F. subglutinans, Periconia sp., Ramichloridium sp., Scolecobasidium sp., Trichoderma sp. 2 and Ulocladium sp. The species distribution can be categorized according to the number of soil types in which each species was identified (species frequency in Table 2), and number of species with different distributions was shown in Figure 1.

Generally, according to Table 2, the most predominant species were Aspergillus spp., Alternaria

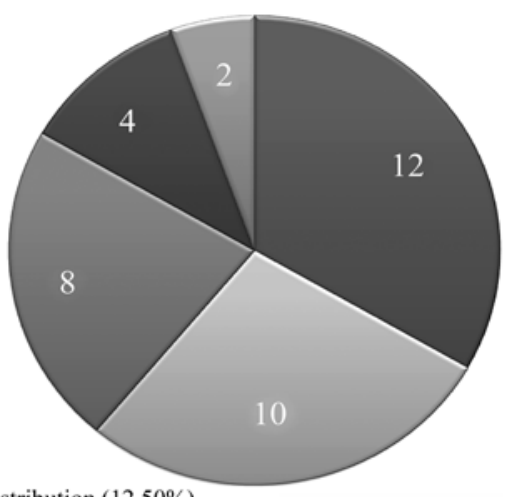

- Very narrow distribution $(12.50 \%)$

$\checkmark$ Narrow distribution $(25.00 \%)$

- Moderate distribution (37.50\% and 50\%)

- Broad distribution (75.00\% and $78.50 \%$ )

“ Very broad distribution (100\%)

Figure 1. Number of fungal species with different distributions in eight different soil types 
sp., Fusarium spp., Mortierella sp. and Penicillium spp. Kiković et al. (1997) found Penicillium, Aspergillus and Cladosporium spp. as common species in alluvium soil samples from Malo Rudare, Serbia. This result can also be compared to the results obtained by authors from all over the world where those species were also reported as common species in soybean soil rhizosphere in India (Maisuria, Patel, 2009), soil and litter samples of Forest Reserve in Trat Province in Thailand (Puangsombat et al., 2010) and litter samples from different forest types in China (Song et al., 2004). It is known that even in tropical forests, many taxa are similar to taxa found in temperate latitudes, and the numbers of species for a particular tropical soil are normally the same or even lower than those observed for soils in temperate regions (Gams, 2007). Fungi from the genera Penicillium, Aspergillus, Cladosporium, Fusarium, Rhizopus, Mucor, Phoma and Verticillium were even found in reservoirs of lakes and rivers in Serbia (Ranković, 2005). Similar fungal communities were found in Ohrid Lake in Macedonia, Bosnian River as well, and even in Estonian lakes (Čomić et al., 2010). This was expected because soil fungi spread easily and most of them have a cosmopolitan distribution and thermophilic and heat-resistant species are largely cosmopolitan (Gams, 2007).

Soil fungi with an abundance of less than $500 \mathrm{CFU} \mathrm{g}^{-1}$ wet weight soil can be considered as rare species (Puangsombat et al., 2010), while those with an abundance of more than $500 \mathrm{CFU} \mathrm{g}^{-1}$ wet weight soil can be considered as common species (Table 2). As seen in
Table 2, one species can be rare in one soil type while it is common in another, for example, F. oxysporum. Rasulić et al. (2012) did not find any correlation between the land use and the total number of microflora and actinomycetes, ammonifiers, azotobacter and oligotrophiles. On the contrary, in this study, a correlation between the land use and the total abundance of soil fungi was found for samples S8, S3 and S4, which were all used as arable land and the total abundance was the highest compared to all other soil types.

Similarity index. Similarities of fungal communities in different soil type samples were analysed using Sorensen's Index. If Sorensen's index was higher than $55 \%$, soil samples were considered to have similar fungal communities (Puangsombat et al., 2010). The highest similarity of soil fungi was noticed between S3 and S8 $(72.72 \%)$, which were both arable-land with a low or moderate CEC and organic matter; followed by S1 and S2 (72.00\%), which were forest and meadow, respectively and had no $\mathrm{CaCO}_{3}$ and a high or moderate CEC (Table 3). Fungal community composition is known to be more similar in soils having similar soil moisture, organic matter, $\mathrm{pH}$ and electrical conductivity (Houston et al., 1998).

A value of Sorensen's index between 35-55\% for soil samples indicates moderate similarity, while a value lower than $35 \%$ indicates a low similarity between samples. The lowest similarity between soil fungal communities can be noticed between sample S1 (Cambisol, forest) compared with samples S6 (28.57\%) and S7 (30.77\%), which were both used as garden soils (Table 3 ).

Table 3. Sorensen's index of similarity (\%) of soil fungal communities between different soil groups

\begin{tabular}{lcccccccc}
\hline & S1 & S2 & S3 & S4 & S5 & S6 & S7 & S8 \\
\hline S1 & - & $\mathbf{7 2 . 0 0 *}^{*}$ & 44.44 & 52.63 & 52.63 & $\mathbf{2 8 . 5 7}^{* *}$ & $\mathbf{3 0 . 7 7 * *}^{* *}$ & 46.15 \\
S2 & & - & $\mathbf{5 6 . 2 5 *}^{*}$ & $\mathbf{5 8 . 3 3 *}^{*}$ & $\mathbf{5 8 . 3 3}^{*}$ & 38.46 & 38.71 & $\mathbf{5 8 . 0 6}^{*}$ \\
S3 & & & - & 53.84 & 53.84 & 42.86 & 36.36 & $\mathbf{7 2 . 7 2}^{*}$ \\
S4 & & & & - & $\mathbf{6 6 . 6 7 *}^{*}$ & 50.00 & 48.00 & 40.00 \\
S5 & & & & - & $\mathbf{6 0 . 0 0 *}^{*}$ & 40.00 & 48.00 \\
S6 & & & & & & - & 44.44 & 44.44 \\
S7 & & & & & & & - & 43.75 \\
S8 & & & & & & & - \\
\hline
\end{tabular}

Note. S1 - Cambisol, S2 - Leptosol, S3 - Arenosol, S4 - Solonetz, S5 - Gleysol, S6 - Vertisol, S7 - Fluvisol, S8 - Chernozem; * - values marked with one asterix indicate high similarities between compared soil samples; ** - values marked with two asterix indicate low similarities between compared samples.

Diversity index. The Shannon-Wiener diversity index indicated the highest diversity of soil fungi in Chernozem (S8), Fluvisol (S7) and Arenosol (S3), all used as arable-land or garden soil (Table 4). The lowest diversity was recorded in a Gleysol (S5) under a meadow, which can be explained by poor aeration and a poor water regime that negatively affected biodiversity despite a high organic matter content and CEC. Gleysol is characterized by the anaerobic decomposition of organic residues, and at the bottom of the solum, anaerobic conditions are permanently present, while aeration is occasionally present in the upper horizons in the zone (Pekeč et al., 2011).
Relationship of soil fungi with soil physical and chemical properties. The relationship between the soil fungi with soil physical and chemical properties was analysed by canonical correlation analysis (CCA) and the results in Figure 2 show that some fungi correlated positively with organic matter, CEC and the percentage of coarse sand (CS), fine sand (FS), silt (S) and clay (C).

The soil fungi with the closest and most positive relationship to organic matter, CEC and coarse sand (CS) were Trichoderma spp. (F36, F37), Rhizopus sp. (F32), Paecilomyces sp. (F26), Mucor sp. (F25) and Hyalodendron sp. (F22). These fungi appeared in

Table 4. Total number of species, total abundance and Shannon-Wiener's diversity index of soil fungi in different soil types

\begin{tabular}{cccc}
\hline $\begin{array}{c}\text { Soil } \\
\text { samples }\end{array}$ & $\begin{array}{c}\text { Soil } \\
\text { group }\end{array}$ & $\begin{array}{c}\text { Total No. } \\
\text { of species }\end{array}$ & $\begin{array}{c}\text { Total abundance, } \\
\text { CFU g-1 } \\
\text { dry weight soil }\end{array}$ \\
\hline S1 & Cambisol & 10 & $15.996 \times 10^{3}$ \\
S2 & Leptosol & 15 & $18.564 \times 10^{3}$ \\
S3 & Arenosol & 17 & $20.850 \times 10^{3}$ \\
S4 & Solonetz & 9 & $19.425 \times 10^{3}$ \\
S5 & Gleysol & 9 & $16.282 \times 10^{3}$ \\
S6 & Fertisol & 11 & $13.993 \times 10^{3}$ \\
S7 & Fluvisol & 16 & $17.994 \times 10^{3}$ \\
S8 & & 16 & $23.422 \times 10^{3}$ \\
\hline
\end{tabular}




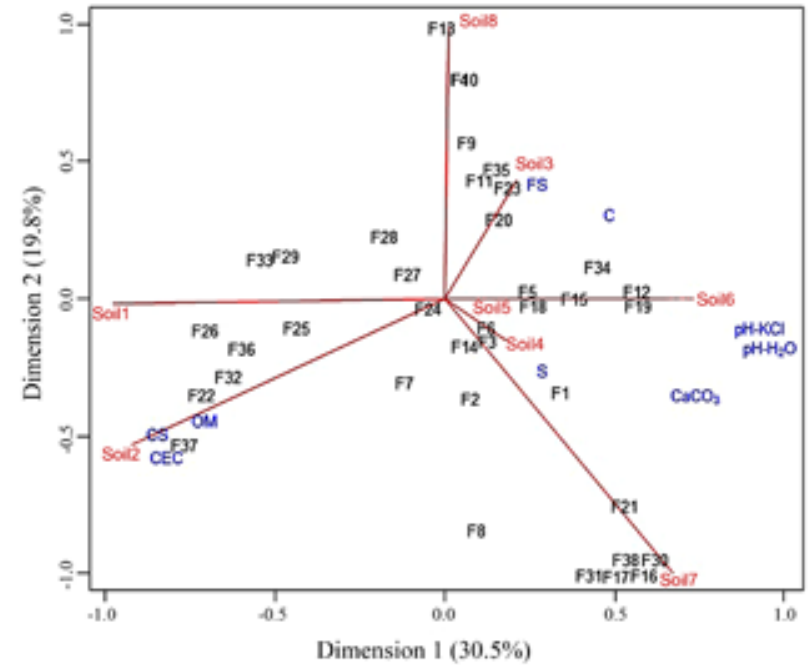

$\mathrm{CaCO}_{3}$ - calcium carbonate, $\mathrm{OM}$ - organic matter, $\mathrm{CEC}$ - cation exchange capacity; content of particles in soil: CS - coarse sand, FS - fine sand, S - silt, C - clay

Figure 2. The relationship of soil fungi with physical and chemical soil properties analysed by canonical correlation analysis (CCA)

soils S1, S2, S3 and additionally S8 for Mucor sp. and Rhizopus sp., and S4 for Hyalodendron sp. (Fig. 2). The adsorptive complex of soil depends on the clay content, clay type and humus content (Belić et al., 2011). A higher adsorptive capacity is characteristic of heavy textured soils, especially with higher amounts of montmorillonite clay and organic matter. It is known that species such as Mucor sp. prefer high moisture content, while both Mucor sp. and Trichoderma spp. prefer higher amounts of organic matter (Grishkan et al., 2005). This was confirmed by our research in which the presence of Mucor sp. and Trichoderma sp. was found in soil samples with such characteristics. These two species were found even at the bottom or littoral samples of eutrophic reservoirs (Ranković, 2005). Penicillium spp., Trichoderma spp., Cladosporium sp., Herbarum sp., Alternaria sp., Mucor sp., Aspergillus spp. and Rhizopus nigricans have been reported as users of both single carbohydrates and recalcitrant substances (Song et al., 2004), which can explain the positive relationship of those fungi with organic matter in this study as well.

Soils that contain much clay and dust can better retain water and nutrients and provide favourable conditions for microbial activity (Ćirić et al., 2012). In this study, a positive relationship with the clay content was found for Aspergillus parasiticus (F5), Fusarium proliferatum (F15), $F$. solani (F18) and unidentified mycelia with pycnidia (F34). Those species were mostly identified in soils S3, $\mathrm{S} 4, \mathrm{~S} 5$ and S6, and additionally in S2, S7, S8 (for F. solani) and $\mathrm{S} 7$ (for $A$. parasiticus) (Fig. 2).

A positive relationship with $\mathrm{FS}$ was found for Fusarium subglutinans (F19), Fusarium sp. (F20), Epicoccum sp. (F12) and Chaetomium sp. (F9), which occurred mostly in soils S3 and S6, as well as S4 (Chaetomium sp.) and S5 (Fusarium sp.) (Fig. 2). Some species such as Paecilomyces sp. and Chaetomium sp. are able to grow in the presence of $\mathrm{Na}$ and $\mathrm{Ca}$ salts (Steiman et al., 2004), which are characteristic of the solonetz soil type in which this species was identified in this study. Solonetz is known to have a strong textural differentiation; the surface horizon has a lighter, usually loamy, texture and the subsurface horizon is very clayic and alkaline (Belić et al., 2012).
No relationship between soil fungi with $\mathrm{pH}$ and $\mathrm{CaCO}_{3}$ was observed in any soil samples, which partly agrees with the results of Puangsombat et al. (2010).

\section{Conclusions}

1. Among all 38 identified soil fungi, the most common were organic matter (OM) decomposers. Generally, predominant species were Aspergillus spp., Alternaria sp., Fusarium spp., Mortierella sp. and Penicillium spp.

2. The highest similarities in soil fungi composition were noticed between Arenosol and Chernozem, both used as arable lands, while the lowest similarities in soil fungal communities were noticed between forest Cambisol compared with Vertisol and Fluvisol, both used as garden soils.

3. The highest diversity, as expected, was recorded in Chernozem (arable land), while the lowest diversity was recorded in Gleysol (meadow) that had poor aeration and a poor water regime, which negatively affected biodiversity.

4. Trichoderma spp., Rhizopus sp.,Paecilomyces sp., Mucor sp. and Hyalodendron sp. had a positive relationship with organic matter, cation exchange capacity (CEC) and coarse sand (CS), while a positive relationship with the clay content was found for Aspergillus parasiticus, Fusarium proliferatum, F. solani and unidentified mycelia with pycnidia.

5. Fungal characterization of different soil types provides important information relating to soil fertility, and these are the first results of fungal biodiversity screening in soil types in Serbia.

\section{Acknowledgments}

This research was a part of project TR 031025 supported by Ministry of Education, Science and Technological Development of Republic of Serbia.

Received 25012017 Accepted 17072017

\section{References}

1. Belić M., Nešić L., Ćirić V., Vasin J., Milošev D., Šeremešić S. 2011. Characteristics and classification of gleyic soils of Banat. Field and Vegetable Crops Research, 48: 375-382.

2. Belić M., Nešić L., Dimitrijević M., Petrović S., Ćirić V., Pekeč S., Vasin J. 2012. Impact of reclamation practices on the content and qualitative composition of exchangeable base cations of the solonetz soil. Australian Journal of Agricultural Research, 6 (10): 1471-1480.

3. Bridge P., Spooner B. 2001. Soil fungi: diversity and detection. Plant and Soil. 232 (1-2): 147-154.

https://doi.org/10.1023/A:1010346305799

4. Cannon P. 1999. Options and constraints in rapid diversity analysis of fungi in natural ecosystems. Fungal Diversity, 2: $1-15$.

5. Cirić V., Manojlovic M., Nesic L., Belic M. 2012. Soil dry aggregate size distribution: effects of soil type and land use. Journal of Soil Science and Plant Nutrition, 12: 689-703.

6. Ćirić V., Nešić L., Belić M., Benka P., Radovanović D. 2016. Can soils of Vojvodina support sustainable intensification of agriculture? The International Bioscience Conference and the $6^{\text {th }}$ International PSU-UNS Bioscience Conference IBSC 2016. Book of Abstracts. Novi Sad, Serbia, p. 287-288.

7. Čomić L., Ranković B., Novevska V., Ostojić A. 2010. Diversity and dynamics of the fungal community in Lake Ohrid. Aquatic Biology, 9 (2): 169-176. https://doi.org/10.3354/ab00248 
8. Gams W. 2007. Biodiversity of soil-inhabiting fungi. Biodiversity and Conservation. 16: 69-72. https://doi.org/10.1007/s10531-006-9121-y

9. Grishkan I., Tsatskin A., Nevo E. 2005. Diversity of cultured microfungal communities in surface horizons of soils on different lithologies in upper Galilee, Israel. European Journal of Soil Biology. 44: 180-190. https://doi.org/10.1016/j.ejsobi.2008.01.001

10. Houston A. P. C., Visser S., Lautenschager R. A. 1998. Microbial process and fungal community structure in soils from clear-cut and unharvested areas of two mixed wood forest. Canadian Journal of Botany, 76: 630-640.

11. Jeewon R., Hyde K. D. 2007. Detection and diversity of fungi from environmental samples: traditional versus molecular approaches. Varma A., Oelmuller R. (eds.) Advanced techniques in soil microbiologv. p. 1-15. https://doi.org/10.1007/978-3-540-70865-0 1

12. Kiković D., Raičević V., Mićanović D., Deletić N. 1997. The effect of heavy metals on the smonitza and alluvium soils microflora in the area of Kosovska Mitrovica. Dragović S. (ed.) Land use, conservation and management, p. 427-435 (in Serbian).

13. Lauber C. L., Strickland M. S., Bradford M. A., Fierer N. 2008. The influence of soil properties on the structure of bacterial and fungal communities across land-use types. Soil Biologv and Biochemistrv. 40: 2407-2415. https://doi.org/10.1016/j.soilbio.2008.05.021

14. Lee K. E., Pankhurst C.E. 1992. Soil organisms and sustainable productivity. Australian Journal of Soil Sciences, 30: 85-92. htttps://doi.org/10.1071/SR9920855

15. Leslie J. F., Summerell B. A. 2006. The Fusarium laboratory manual ( ${ }^{\text {st }}$ ed.). https://doi.org/10.1002/9780470278376

16. Maisuria K. M., Patel S. T. 2009. Seed germinability, root and shoot length and vigour index of soybean as influenced by rhizosphere fungi. Karnataka Journal of Agricultural Sciences, 22: 1120-1122.

17. Nešić L. 2011. Soil irrigability in Vojvodina. Belić S. (ed.). Water quality for irrigation, p. 3-27.

18. Pekeč S., Belić M., Nešić L., Orlović S., Ivanišević P. 2011. Water physical properties of eugley in a protected part of alluvial plains of the central Danube Basin. African Journal of Agricultural Research, 6 (7): 1717-1725.
19. Puangsombat P., Sangwanit U., Marod D. 2010. Diversity of soil fungi in different land use types in the Kum-Huai Raeng Forest Reserve, Trat Province. Natural Sciences, 44: $1162-1175$.

20. Ranković B. 2005. Five Serbian reservoirs contain different fungal propagules. Mvcologia. 97: 50-56. https://doi.org/10.1080/15572536.2006.11832838

21. Rasulić N., Delić D., Stojković-Srbinović O., Kuzmanović Đ., Jošić D. 2012. Microbiological properties of rankers in the region of Western Serbia. Field and Vegetable Crop Research, 49: 173-176.

22. Rousk J., Bååth E., Brookes P. C., Lauber C. L., Lozupone C., Caporaso J. G., Knight R., Fierer N. 2010. Soil bacterial and fungal communities across a $\mathrm{pH}$ gradient in an arable soil. The ISME Journal. 4 (10): 1340-1351. https://doi.org/10.1038/ismej.2010.58

23. Schiefer J., Lair G. J., Blum W. E. 2015. Indicators for the definition of land quality as a basis for the sustainable intensification of agricultural production. International Soil and Water Conservation Research. 3: 42-49. https://doi.org/10.1016/j.iswcr.2015.03.003

24. Six J., Frey S. D., Thiet R. K., Batten K. M. 2006. Bacterial and fungal contributions to carbon sequestration in agroecosystems. Soil Science Societv of America Journal, 70: 555-569. https://doi.org/10.2136/sssaj2004.0347

25. Song F. Q., Tian X. J., Li Z. Q., Yang C. L., Chen B., Hao J. J., Zhu J. 2004. Diversity of filamentous fungi in organic layers of two forests in Zijin Mountain. Journal of Forest Research. 15: 273-279. https://doi.org/10.1007/BF02844951

26. Steiman R., Ford L., Ducros V., Lafond J. L., Guiraud P. 2004. First survey of fungi in hypersaline soil and water of Mono Lake area (California). Antonie van Leeuwenhoek, 85 (1): 69-83. https://doi.org/10.1023/B:ANTO.0000020150.91058.4d

27. Thun R., Herrmann R., Knickmann E. 1955. The analysis of soils ( $3^{\text {rd }}$ ed.) (in German).

28. Watanabe T. 2010. Pictorial atlas of soil and seed fungi: morphologies of cultured fungi and key to species ( $\left.3^{\text {rd }} \mathrm{ed}.\right)$. https://doi.org/10.1201/EBK1439804193

29. WRB. 2014. World reference base for soil resources 2014. World Soil Resources Report 106. FAO, Rome.

ISSN 1392-3196 / e-ISSN 2335-8947

Zemdirbyste-Agriculture, vol. 104, No. 4 (2017), p. 305-310

DOI 10.13080/z-a.2017.104.039

\title{
Dirvožemio savybių įtaka dirvožemio grybų įvairovei
}

\author{
S. Tančić Živanov ${ }^{1}$, L. Nešić ${ }^{2}$, R. Jevtić ${ }^{1}$, M. Belić², V. Ćirić ${ }^{2}$ M. Lalošević1 ${ }^{2}$ J. Veselić1 \\ ${ }^{1}$ Novi Sad lauko augalų ir daržovių institutas, Serbija \\ ${ }^{2}$ Novi Sad universitetas, Serbija
}

\section{Santrauka}

Tyrimo tikslas - nustatyti dirvožemio savybių įtaką dirvožemio grybų biologinei ịvairovei. Išanalizavus aštuonių skirtingų dirvožemio tipų, turinčių nevienodą dirvožemio granuliometrinę sudètį, ą organinių medžiagų ir karbonatų kieki, pH, katijonu mainu geba ir žemès naudojima, grybu ịvairovę nustatytos 38 skirtingos grybu rūšys, kurios buvo sugrupuotos ị 24 gentis. Iš visų identifikuotų dirvožemio grybų dažniausi buvo organinių medžiagų skaidytojai. Dažniausiai pasitaikančios rūšys buvo Aspergillus spp., Alternaria sp., Fusarium spp., Mortierella sp. ir Penicillium spp. Didžiausias grybų bendrijų panašumas buvo nustatytas ariamoje žemeje su maža arba vidutine katijonų mainų geba ir organinių medžiagų kiekiu, o mažiausiai panašumų buvo tarp miško rudžemio (Cambisol) ir sodo dirvožemių. Shannon-Wiener indeksas parodė didžiausią juodžemio (Chenozem), salpžemio (Fluvisol) ir smèlžemio (Arenosol) grybų ịvairovę, kai šie dirvožemiai buvo naudojama kaip ariama žemè arba sodo dirvožemis. Mažiausia ịvairovė nustatyta pievoje šlynžemyje (Gleysol) dèl prastų aeracijos ir vandens režimo. Kanoninès koreliacijos analizė išryškino dirvožemio grybų ryši su visais dirvožemio aplinkos veiksniais ir parodè, kad kai kurie dirvožemio grybai buvo teigiamai susiję su organinėmis medžiagomis, smèlio ir molio kiekiu.

Reikšminiai žodžiai: biologinè įvairovè, dirvožemio grybai, žemės naudojimas. 